\title{
Dairi storytelling and stories in the Batak Reader of Herman Neubronner van der Tuuk
}

\author{
CLARA BRAKEL-PAPENHUYZEN
}

\begin{abstract}
In this article I first discuss how texts of Dairi stories collected in the nineteenth century by Herman Neubronner van der Tuuk relate to storytelling, and question whether the development of written versions of stories necessarily endangers the practice of storytelling. Then I investigate how written versions of Dairi stories in Van der Tuuk's Batak Reader relate to each other and to the printed text, based on texts in manuscripts collected by Van der Tuuk. In conclusion I discuss the possible aim of Van der Tuuk's Batak Reader, focussing on the Dairi section, which has not been dealt with in earlier publications.
\end{abstract}

KEYWORDS

North Sumatra; Van der Tuuk collection; Dairi stories; ritual function; storytelling; Batak reader.

\section{INTRODUCTION ${ }^{1}$}

In my recent book Dairi stories and Pakpak storytelling (Brakel-Papenhuyzen 2014) the story is presented of Si Buah Mburle, a boy shaped like a wild mango fruit, as performed by Sonang Sitakar, a professional Pakpak-Dairi storyteller, in the North Sumatran village of Sukaramai in 1979 (See Picture 1). Apparently, this story was already popular in the nineteenth century, when the well-known

1 This article is partly based on a presentation for the 8th EuroSEAS Conference in Vienna on 13 August 2015 during the panel on "Stories and Storytelling in the Indonesian Archipelago".

CLARA BRAKEL-PAPENHUYZEN received her PhD in Languages and Cultures of Southeast Asia from Leiden University in 1988, where she has lectured on the Performing Arts of Southeast Asia. Her publications include The bedhaya court dances of Central Java (1992, Leiden: Brill), Dairi stories and Pakpak storytelling; A storytelling tradition from the North Sumatran Rainforest (2014, Leiden: Brill/KITLV Press). After working as a senior researcher at the International Institute of Asian Studies (IIAS) in Leiden, the Centre National de la Recherche Scientifique (CNRS) in Marseille, and the Hebrew University of Jerusalem, she currently researches oral and written traditions of Indonesia and Performing Arts of Asia in Leiden. Clara Brakel-Papenhuyzen may be contacted at: clara.brakel@gmail.com.

(C) 2016 Faculty of Humanities, University of Indonesia

CLARA BRAKEL-PAPENHUYZEN | DOI: 10.17510/wacana.v17i2.443 
Dutch linguist Herman Neubronner van der Tuuk collected a written story with the same theme during his stay in Barus (1852 - 1857). ${ }^{2}$ As discussed in the book, the performance of the story was very different from the ninteenthcentury written text: Sonang Sitakar told his story partly in a poetic singing or chanting style, which he alternated with narration, while the Dairi story written for Van der Tuuk is entirely in prose.

In an early letter to his employer, the Dutch Bible Society, Van der Tuuk maintains that "Batak" stories belong to "unwritten literature" (Groeneboer 2002: 136). In the same letter he writes that, because he could not correctly note stories down "from the mouth of the person telling the story", he had stories written on paper by "a skilled datu (ritual specialist or shaman)", primarily in order to obtain reliable material for his linguistic studies of "Batak" languages, as discussed in this article.

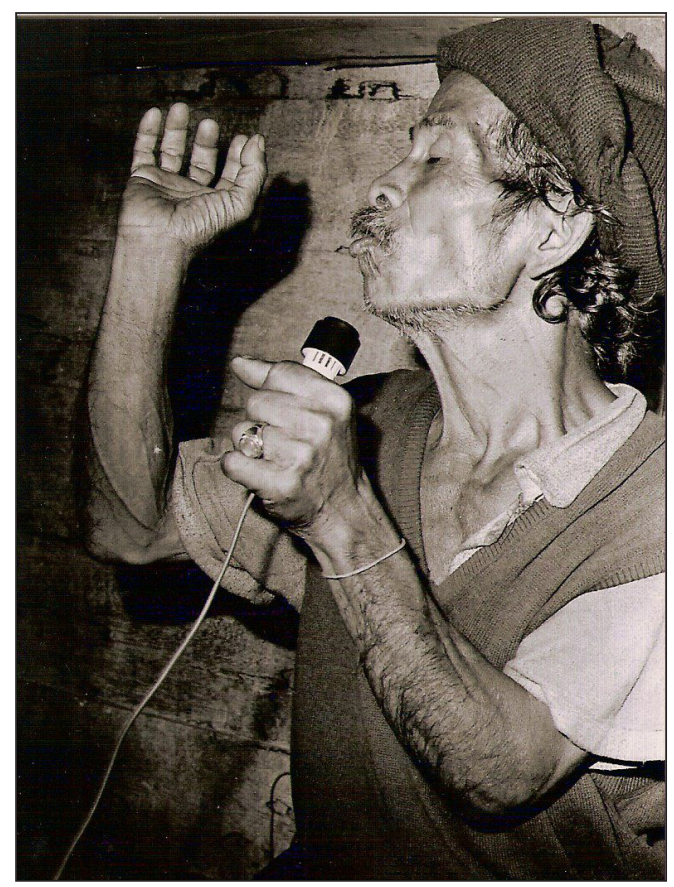

Picture 1. Pakpak-Dairi storyteller Sonang Sitakar, North Sumatra (photograph by the author, 1979).

In the late 1970's, at the time of our research, storytelling was considered an endangered oral tradition in the Dairi region of North Sumatra (BrakelPapenhuyzen 2014: Preface), yet, according to the storyteller Sonang Sitakar, there used to be many storytellers in the area [interview after the recording in 1979]. Sonang Sitakar as well as Van der Tuuk's writers of stories claim to

2 Being the first to make a linguistic study of the languages of North Sumatra, Van der Tuuk collected a large number of manuscripts in Dairi and other Batak languages during his stay on the west coast of Sumatra. For a discussion of this collection, which is kept in Leiden University Library, see Brakel-Papenhuyzen 2014, Chapter 2. 
have heard their story from other people, usually in a formulaic introduction to the story. In view of the widespread literacy among Batak peoples reported by Van der Tuuk (Groeneboer 2002: 115) and others (Kozok 2000), many Dairi storytellers must have been literate, and thus were able to base their storytelling not merely on stories they heard, but could also use written sources, as is common in other regions of the Archipelago (Brakel-Papenhuyzen 2004). Before the introduction of paper, letters and laments (andung) were written on bamboo, as well as summaries of stories in Dairi and other Batak languages. Several of these, which were collected and transcribed by Van der Tuuk, have been discussed and published in my book Dairi stories and Pakpak storytelling.

In this article I first discuss how texts of Dairi stories collected in the nineteenth century relate to storytelling, and question whether the development of written versions of stories necessarily endangers the practice of storytelling. Then I investigate how written versions of Dairi stories in Van der Tuuk's Batak Reader relate to each other and the printed text, based on texts in manuscripts collected by Van der Tuuk. I conclude by suggesting the possible aim of Van der Tuuk's Batak Reader, focussing on the Dairi section, which has not been discussed in earlier publications.

\section{SUKUT-SUKUTEN, POPULAR STORIES}

As I have not come across any restrictions for telling Dairi stories, generally called sukut-sukuten, it seems that these popular stories may be told at any occasion. According to Voorhoeve $(1927: 15,19)$, popular Batak stories are told in informal settings, a hut in the forest, a small coffee-shop, or as a bed-time story, while Moore writes in her PhD thesis on Songs of the Pakpak of North Sumatra that they may also be told in a more formal setting, such as a wedding celebration (Moore 1985). In the mid-nineteenth century, storytelling must have been so common, that Van der Tuuk managed to collect a large number of Batak stories, sukut-sukuten in Dairi, within a relatively short period. In his letter to the Dutch Bible Society dated 5 May 1852 he maintains that the Batak peoples never write their stories down and that their interest in literature is restricted to ritual instruction of the poda, referring to ritual texts witten in tree-bark books (pustaha) which are used by guru or datu, shamans and ritual specialists (Groeneboer 2002: 136). ${ }^{3}$ Yet a few months later, in a letter dated 24 August 1852, Van der Tuuk writes that he has no time to make a copy of his dictionary, because every day bamboos inscribed with stories are offered to him, which he first has to copy and then study in the presence of the man who wrote them down (Groeneboer 2002: 154). This probably indicates that besides laments and letters, stories were also written on bamboo in Dairi and other Batak areas before Van der Tuuk's arrival - in fact, they were also included in some pustaha.

In his letter, Van der Tuuk explains the term poda as: "voorschriften voor de datoes omtrent het vervaardigen zoowel van behoed- als geneesmiddelen, het mengen van vergift en tegengift, en alles wat betrekking heeft tot het raadplegen der toekomst" (Van der Tuuk 1852 quoted in Groeneboer 2002: 132). 
At first Van der Tuuk transcribed these stories from bamboo on paper in Latin script, later he employed local scribes to make transcriptions and write stories for him. As an abundance of written material was offered to Van der Tuuk, to note down a story-text in writing must have been quite common. It is even possible that the writing down of stories or other texts developed into a commercial practise, in view of Van der Tuuk's remark in a letter dated (?) August 1856, that he needs a lot of time to check not only any transcriptions made for him, but also to carefully read the "merchandise", inscribed bamboos offered to him, because if he does not do that, he is tricked and "all sorts of stuff is put into my hands" ${ }^{4}$ (Van der Tuuk 1856 quoted in Groeneboer 2002: 317).

Now it is obvious that the process of writing influences form and content of a text, just as a performance setting does. This is especially so when the person at whose request a story is performed or written down has specific demands, which Van der Tuuk definitely had. In a letter dated 24 August 1852 he writes that he has to sit with the man who writes the stories down for him in order to correct these as much as possible, as "they" [the writers] do not express themselves in a clear manner, because they imagine that the reader has already often heard the story being recited (Groeneboer 2002: 151-152). ${ }^{5}$ In fact the texts written on bamboo may also have been commissioned by someone, who is addressed as ale tuan or raja at the beginning and/or end of the story, often with the addition that the writer is a poor man, or does not know whether the story is true or not.

As described in my book, stories written on bamboo have specific formal structures and ways of expression. After comparing various versions of these stories, I have suggested that there was a certain freedom in the storyline at the time when Van der Tuuk collected his stories, which disappeared later when stories were published in print (Brakel-Papenhuyzen 2014: 93). Apparently the process of publication led to a fixation of content and form of a story, which Van der Tuuk may not have been aware of, or if he was, not have considered a problem. In his letters to the Dutch Bible Society, Van der Tuuk repeatedly points out that Batak stories should be published, and in a letter dated 25 May 1856 he argues that this would help to preserve the Batak language and

\footnotetext{
“Men heeft bij het Bataksch misschien veel meer werk dan bij het bestudeeren van een andere taal, want de meeste geschriften zijn op bamboe, en daar deze teveel plaats innemen, ben ik verpligt de meeste der geschriften die men mij brengt, of zelve af te schrijven, of na te zien zoo ik ze laat afschrijven. Dat verslindt oneindig veel tijd, en wil ik dus vertalen dan moet ik die dingen laten loopen, hetgeen ook al weer niet raadzaam is, daar ik op die wijze de toevoer van geschriften naar mij doe ophouden, of de Bataks, die een vreemdeling gaarne voor het lapje houden, in de verleiding breng mij allerlei dingen in de hand te stoppen, zoodra zij zien dat ik hunne koopwaar niet nalees. In den beginne toen ik nog niet zoo vlug handschriften kon lezen, hebben de heeren dat mij verschillende malen geleverd" (Van der Tuuk 1856 quoted in Groeneboer 2002: 317).

$5 \quad$ "Bij het laten opschrijven hunner verhalen ben ik genoodzaakt, den man die de bij hen bekende verhalen boekt bij mij te nemen, om zooveel mogelijk ze te corrigeren, daar zij alles behalve roem kunnen dragen op een eenigszins heldere wijze van uitdrukking, en zulks wel omdat zij den lezer zich voorstellen als iemand die zoo' $n$ verhaal reeds meermalen heeft hooren opdreunen" (Van der Tuuk 1852 quoted in Groeneboer 2002: 151).
} 
identity, and protect these against the increasing influence of Malay and Islam (Groeneboer 2002: 292-293). ${ }^{6}$ While one may question whether the publication of these stories could really help to preserve the local language, identity, moral values and history, it is also questionable whether a performance tradition can be "saved" by writing stories down, or by recording a performance - as was done during our fieldwork in 1979? I hope that future research can answer this question.

\section{RITUAL STORIES}

Not all stories collected by Van der Tuuk are sukut-sukuten that can be told at any time or place. There are also Dairi stories that must be told in the context of a ritual, and performed by a ritual specialist (guru or datu). Usually such a story tells about the origin of that ritual, in order to justify its performance. Some of these ritual stories have been preserved in writing, some in tree-bark books or inscribed on bamboo, others in Latin transcription on paper.

\section{A. DATU TONGGAL ${ }^{7}$ NI BEGU}

One of the stories presented in my book on Dairi Stories and Pakpak Storytelling, entitled Datu Tonggal ni Begu by Van der Tuuk, is in fact a ritual story. Its opening line says that it holds "instruction in the text of the invocation to the god(s)" (pedah ni kata-kata ni mangmang debata) (Brakel-Papenhuyzen 2014: 129). During his stay in Barus, Van der Tuuk transcribed this story in Latin characters from an original on bamboo. This transcription is now kept in Leiden University Library (MS Or. 3406: 170/175 - 173/178). The story may have been written on bamboo for a shaman's personal use, or for someone addressed in the opening and final lines as "lord" and "ruler" (ale tuan, ale raja). Following the opening line, the text starts with a well-known formulaic invitation to the gods above, below and on the earth (see Illustration 1, MS Or. 3406: 170):

Asa turun ma kamu debata di atas Manangke ma kamu debata di teruh Tumundul ma kamu debata di tengah Asa tengah turun ma kamu
Descend, you Gods from above Ascend, you Gods from below Sit, you Gods in the middle And descend to the middle

The text continues with an invocation of "si dayang batari debata", divine female spirits or goddesses of the eight points of the compass:

$6 \quad$ "In plaats van den Bijbel te verspreiden moet men zich eerst vergenoegen met het verspreiden van Bataksche geschriften om de leeslust aan te moedigen, en de nationaliteit van den Batak tegen den invloed van den Islam te bewaren, want reeds heeft de Islam te Natal en op een gedeelte van deze afdeeling het Bataksch door het Maleisch doen verdringen" (Van der Tuuk 1856 quoted in Groeneboer 2002: 292-293).

7 In the Latin transcription of this text, the name is spelled either as Tonggal or as Tunggal. 
Si Dayang batari debata di purba

Si Dayang batari debata di hagoni

Si Dayang batari debata di dangsina

Si Dayang batari debata di nariti

Si Dayang batari debata di pastima

Si Dayang batara debata di manabia

Si Dayang batari debata di otara

Si Dayang batari debata di irisanna.
Si Dayang, Goddess in the East

Si Dayang, Goddess in the South-east

Si Dayang, Goddess in the South

Si Dayang, Goddess in the South-west

Si Dayang, Goddess in the West

Si Dayang, Goddess in the North-west

Si Dayang, Goddess in the North

Si Dayang, Goddess in the North-east

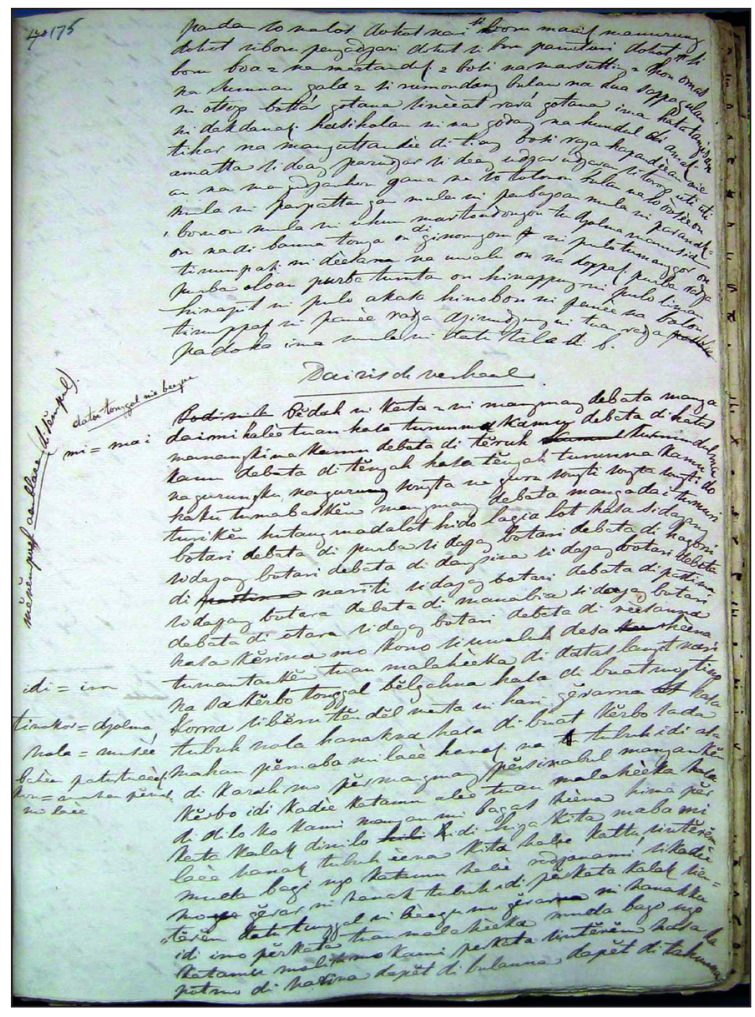

Illustration 1. MS Or. 3406: 170, Datu Tonggal ni Begu.

The story that follows tells about the ancestors of a woman named Beru Tinggi Saribu Tala, starting with Tuan Malaheka and his wife Beru Tendel Mata ni Ari, who have a son name Datu Tonggal ni Begu. The son's granddaughter Beru Tinggi Saribu Tala in the end becomes a female spirit of the fields (begu) named Arlah Tala. (Brakel-Papenhuyzen 2014: 128-137).

\section{B. Guru tonggal Begu or Pemere Beru Si Pitu}

A longer version of this story is also kept in Leiden University Library (MS Or. 3399: 120-171). It was written on paper for Van der Tuuk by one of his helpers and gives detailed information about its ritual context. This must have been at the request of Van der Tuuk, as no informaton about the ritual is given in the text that was transcribed from bamboo. 
Remarkably, the text that was written for Van der Tuuk does not start with an invocation to the gods or the goddesses guarding the eight points of the compass. It opens just like most of the stories that were written down for Van der Tuuk: "Now there was, it is said, a man named Aji Malaheka, his son was named Guru Tonggal Begu" (Asa lot mo kunuken Si Aji Malaheka, anakna mergerar Guru Tonggal Begu). After telling how Beru Tinggi Saribu Tala, the granddaughter of Guru Tonggal Begu, becomes a spirit (begu) named Beru Si Pitu, this story ends with a description of the ritual during which the story should be told.

An introduction to the story states that this is a shaman's story (turi-turin ni guru) named Pemere Beru Si Pitu ${ }^{8}$ (Offering for Beru Si Pitu), which should be told by a guru when a banyan and a fig-tree are planted as a remedy for the people (barang menuan beringin deket kayuara tambar si lakon kalak). Later, at the end of the story, this is explained as follows: "If people lose a child, and mother and child have both died, people should take a sapling of a banyan tree for the burial ritual". ${ }^{9}$

After describing how this ritual must be performed, the text closes as follows: “Thus is the beginning of the Dairi people's [offering to] Beru Si Pitu. From ancient times until now people have been told to plant what is called a 'beringin tepet cilaka', to perform a ritual once in every three years offering a male pig, [and] to prepare an offering of planting [a tree] for the death of young children, offering rice flour, a chicken's egg, a fish, [and] plain cooked rice with the egg and the fish". ${ }^{10}$ (Brakel-Papenhuyzen 2014: 176).

If sukut-sukuten and ritual stories were written down in local script before the arrival of Europeans, this could indicate that Dairi storytellers wanted to memorise at least the main points and actors of a story, and that they did not make up the entire story during a performance. It may also imply that - unlike the singers of laments - the Dairi storyteller does not enter into a trance while telling or chanting the story - as indeed he did not during the performance we recorded in 1979.

Many Dairi stories collected by Van der Tuuk address somebody as raja or tuan, in the beginning or final lines of the story, so apparently the writer wrote the story down at the request of that person. In this respect the written text is not different from a performance - a storyteller also addresses an audience and shapes the story to suit their expectations, or what the person who commissioned the storyteller demands.

The question is, whether professional storytellling, which takes at least

8 In the list of contents on the first page of MS Or. 3399, the title of the story is "Goeroe Tonggal Beegoe".

Brakel-Papenhuyzen 2014: 175: “Muda cilakan kalak mermaten anakna deket beruna, menuanken cilaka kalak, ibuat mo anak beringin".

10 Brakel-Papenhuyzen 2014: 179: “Bagi mo permungkahen kunuken arnia asa lot anak Dairi mer-Beru Si Pitu datang bagena dokken menuan beringin tepet cilaka gerarna mahan kerja ni kalak telu tahun sikali ikerjai babi tonggal, asa lot mahan pemere si tuan tepet cilaka perkelangen si telu tahun idi. Ibereken ugup pagena, tinaruh manuk sada, ikan sada, nakanrentang dengan tinaruh manuk idi deket ikan idi". 
several hours - or evenings - has disappeared since stories have been published in print, as is often assumed. This question is even more pressing for ritual stories: are these still told since conversion to monotheistic religions, or have they disappeared along with the rituals? Contrary to what is often assumed, anthropologists such as Juara Ginting and Johann Angerler report to have witnessed storytelling in the course of a ritual during their fieldwork in North Sumatra (Ginting 1990), Angerler (see his article in this volume). More fieldwork is necessary to establish what is happening to traditional storytelling in the region, and whether professional storytellers like Sonang Sitakar can still be found in North Sumatra.

\section{DAIRI STORIES IN THE BATAK READER}

In accordance with his task as stated in the contract with the Dutch Bible Society, Van der Tuuk used the stories he collected in Barus to prepare linguistic works "as an aid for others to study the language", ${ }^{11}$ (Van der Tuuk 1971: XV). Phrases and expressions from stories have frequently been quoted as examples in his Toba Batak dictionary and in his grammar of Toba Batak, which also illustrates many issues with examples from the Dairi language. The original Dutch version of this grammar, Tobasche spraakkunst (Amsterdam 1864-67), has a reading exercise (leesoefening) with a transliteration in Latin characters of the beginnings of a Toba, a Mandailing and a Dairi story, the English version of the grammar also adds a specimen of the scripts in an Appendix. All three examples have been taken from the Batak Reader; the Dairi example is the fifth story in the third part, entitled "Manuk-manuk Saip Ladang" (the bird Saip Ladang). ${ }^{12}$

Between 1860-1862, before his Toba Grammar ${ }^{13}$ appeared, Van der Tuuk published a Batak Reader (Bataksch Leesboek) in four volumes, the first in 1860 with texts in Toba, the second in 1861 with texts in Mandailing, and the third in 1861 with Dairi stories, followed in 1862 by a fourth volume with notes, comments and a few translations or summaries of stories. Similar to Javanese and Malay text-books that were printed in (a specially designed form of) the original script, the three text-books of Van der Tuuk's Batak Reader published in Amsterdam were all printed in Batak characters by the firm of C. A. Spin $\&$ Zoon. The list of contents in each of these three textbooks is also in Batak script, only the title page is in Latin characters.

The first and second volumes contain Toba and Mandailing popular stories, some riddle-stories (torkan-torkanan) and a few four-line verses (umpama). In Mandailing there are also two laments and a reading exercise (jangka-jangka). The third volume (Derde Stuk) published in 1861 contains the

11 Quoted in the Foreword to the English version of his Grammar of Toba Batak (Van der Tuuk 1971: XV).

12 An earlier article on script and pronounciation of the Toba language, published in the Bijdragen van het Koninklijk Instituut voor Taal-, Land-en Volkenkunde (BKI) in 1856, has the Dairi story of kayuara merlendung (Brakel-Papenhuyzen 2014: 96-101).

13 Van der Tuuk 1864-67: Tobasche spraakkunst (Amsterdam: Muller). 
texts of eleven Dairi stories (Stukken in het Dairisch). Preceding the stories is a list of contents in Dairi characters (isi surat pemasan kata Dairi) and the page numbers on which they start (see Illustration 2). It reads in Latin transcription, with my English translation:

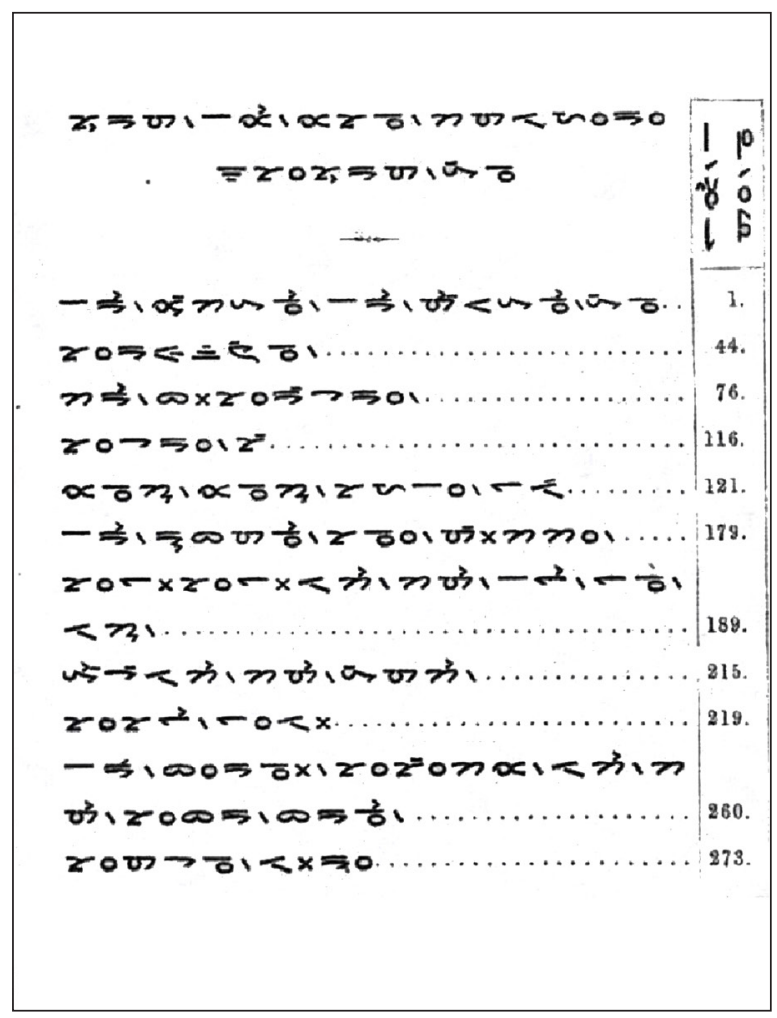

Illustration 2. Bataksch Leesboek III, Inhoudsopgave ('Table of contents').

List of Dairi stories

p. 1. Permungkahen pertengahen ena, 'The beginning of this middle'.

p. 44. Si Raja Uwen, 'Raja Uen', [personal name meaning 'the ruler who must be obeyed'].

p. 76. Kerbo Si Ranggir, 'The water-buffalo Si Ranggir'.

p.116. Si Girsang, 'Girsang' [personal name].

p. 121. Manuk-manuk Saip Ladang, 'The bird Saip Ladang'.

p. 179. Perubaten Si Tongkik, 'The quarrel of the deaf people'.

p. 189. Silo-silo deket pelanduk, 'The otter and the mouse-deer'.

p. 215. Enggang deket etek, 'The hornbill and the sawah-fish'.

p. 219. Si Selido, 'Selido' [personal name].

p. 260. Perbiron Si Singkam deket Si Barbaren, 'The dispute between Singkam and Barbaren'.

p. 273. Si Tagan Dori, 'Tagan Dori' [personal name]. 


\section{PERMUNGKAHEN PERTENGAHEN ENA}

The Dairi part of the Batak Reader opens with a creation-story (scheppingsverhaal) entitled "Permungkahen pertengahen ena" telling about the origin of the earth and its inhabitants. ${ }^{14}$ In view of his task to translate the Bible into Batak languages, this story must have been of particular interest to Van der Tuuk, and it is therefore not surprising that he made a faithful Dutch translation of the story with many comments in lengthy footnotes. The text of the story of "Permungkahen pertengahen ena" is found in two manuscripts written in Dairi characters:

1. MS Or. 3420: 392-412, in a small, regular handwriting, may have been written by Van der Tuuk. The text is almost the same as the text printed in the Batak Reader.

2. MS Or. 3421: 27-54 must be an earlier version of this story, as there are many corrections and deviations from the printed text (see Illustration 3). This text, written in a different handwriting, starts with an introduction mentioning - which is very unusual - the writer's name as Guru Tinuturen. ${ }^{15}$ The writer states that he has written the story for a tuan pandito, a priest, or scholar [Van der Tuuk], hoping that he will be pleased to find [in it] the Dairi rules (bincara).

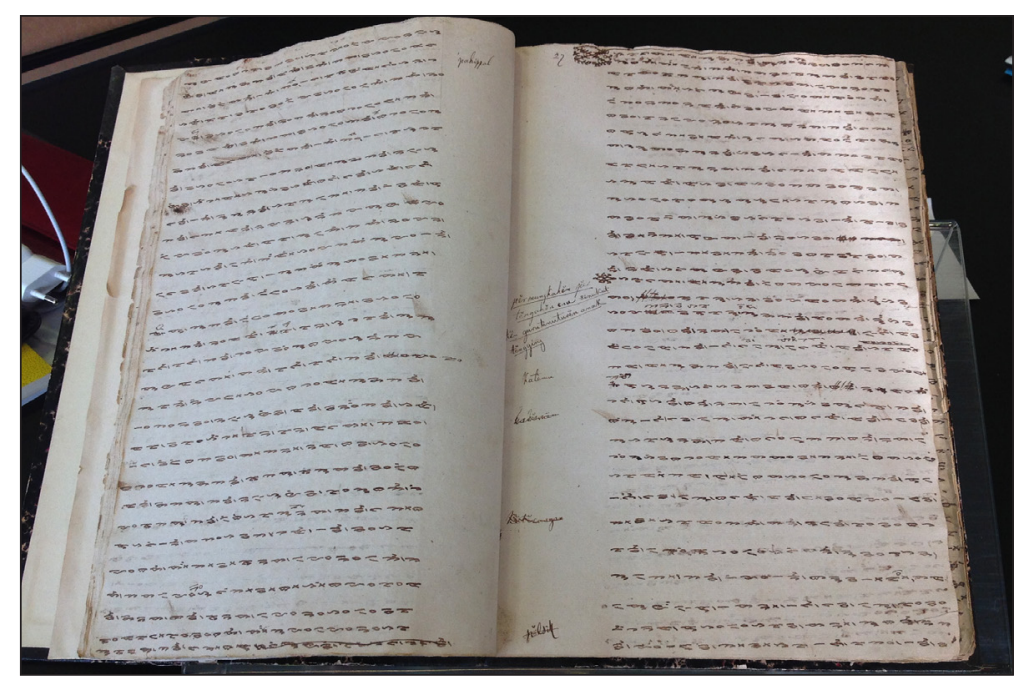

Illustration 3. MS Or. 3421: 27, Permungkahen pertengahen ena.

14 In the fourth volume Van der Tuuk (1862: 48) explains the title as follows: “Batak people divide the world into three sections: 1 . heaven as the dwelling place of the actual gods (the Upper Gods) 2. this middle as the dwelling place of the middle-gods (people, lesser spirits, spooks etc.) and 3. the nether world as the dwelling place of Naga padoha, Rangga puri etc.".

15 In the margin in Latin script is written "Guru Tinuturen Anak Tengging", indicating that the writer or his family came from Tengging. According to Juara Ginting this place is also known as Tongging, and is located in the Karo district near Lake Toba. 
Although not formulated very clearly, the introduction also says that different stories were used in composing this story for Van der Tuuk: "now there is a story of people that I know with the words [or text] of all sorts of stories" (asa lot mo kunuken turi-turin ni kalak kubetoh deket kata ni sukuten nasa si masa). The contents of the story indicate that the writer indeed combined elements from various stories in his text. It first describes the creation of the earth proper and of the first human couple. The second section deals with the increase of the population on earth by introducing the theme of a human being who emerges from inside a bamboo, which also occurs in dynastic histories of Malay rulers, as discussed by J.J. Ras in the Introduction to his edition of the Hikayat Banjar (Ras 1968: 88-89)

In the Batak Reader this introduction has been omitted, the story entitled "Permungkahen pertengahen ena" simply starts with the formulaic: "now there is, they say" (asa lot mo kunuken), followed by the name of the main actor, Debata $i$ datas langit, the god in the sky above. While it is situated in the sky the story describes a situation that was customary in North Sumatra at the time: the debata lives with his wife and helpers (naposo) in a place that is surrounded by forests and behaves like the ruler (raja) of a Dairi settlement (Van der Tuuk 1860-62, Bataksch Leesboek III: 1-2):

Once upon a time long ago, it is told, Debata $i$ datas langit, [a] god in the sky above, came down here. The reason why he came down, they say, was that his wife who was pregnant felt a craving for a pregnant male mouse-deer. His wife, it is told, said: "If you wish, oh son of my Aunt, that this fruit of my body will come into being, you must get me a pregnant male mouse-deer to eat, so that this fruit of my body will come into being". These were the words of the God's spouse.

Then, it is told, the God spoke: "If you say that you must eat a pregnant male mouse-deer, so that what is inside your body will see the light of day, oh Uncle's daughter, I will order my young men to hunt it. Hopefully the mouse-deer that you desire will soon be found, so that I can soon give it as food to you, and our minds will be calm, and your unborn child will no longer be disturbed by ghosts, oh uncle's daughter". These were, they say, the words of the God. Then the God ordered his helper Aji Guru to go hunting, and a crow was told to go with him. ${ }^{16}$

16 In Dairi the text reads: Asa lot mo kunuken debata i datas langit susur arnia mi teruh ena. Ia karnana asa susur ia mi teruh ena, bakin berat daging mo jelmana mengidamken pelanduk tonggal balemen. Asa mongkam mo kunuken jelmana idi: "Muda naing mo katemu urun ale anak mamberu, mi kenggeluhen berat dagingku ena, tulusken bangku pelanduk tonggal balemen panganenku, asa mun kembali dukak berat dagingku ena". Bagi mo kata tinokor debata idi.

Asa mongkam mo debata idi kunuken: "Muda pelanduk balemen ngo nimu ipangan kono asa mi kelerangen si mi bagasen dagingmu idi ale beru ni puhun, kudokken pe iperburu naposonta. Madatuah jumpa tor pelanduk si nipenggarammu idi, asa entor kubereken ipangan kono, asa pelcik penarihinta, malot nenge itokal begu bertihmu idi ale beru ni puhun". Bagi mo kata Debata idi kunuken. Asa idokken Debata idi mo naposona si Haji Guru kunuken merburu. Asa idokken Debata idi mo deket sada kak. (Van der Tuuk 1860-62, Bataksch leesboek III: 1-2). 
Below the sky, the crow finds a dark empty abyss filled only with water. Then the debata who has come down to look for the crow brings light into this darkness (Van der Tuuk 1860-62, Bataksch Leesboek III: 11):

And the debata spoke: "It's alright, crow. You are right, we should really be able to see each other". That's what he said. Then he invoked the eight directions of the compass and then the entire region was seen clearly. ${ }^{17}$

Once there is light, the debata and his helpers construct a raft from the wooden beams they have brought with them, resting it on the head of a billy-goat. The debata places a handful of earth on the raft, it spreads, and on this he brings into being two trees for the crow to sit on. He orders him to stay there, then returns. A mandi-swallow is sent down to keep the crow company and act as a messenger.

At the request of the two birds, Debata $i$ datas langit descends again. He sends the swallow up to ask his wife for a basket with [red] earth. From this earth the debata will create a pair of human beings, which is described as follows (Van der Tuuk 1860-62, Bataksch Leesboek III: 18):

Thereafter, the debata formed this earth into two statues, one in the shape of a man, the other in the shape of a woman. When he had finished shaping the two of them, he laid them in the sun to dry. When the earth he had shaped was dry and hard, he chanted a spell (tabas) over them. After that he blew on them. After he had blown on them seven times, they started breathing. When they were breathing, the debata pronounced a special spell and spoke to them. They answered: "What do you want from me, grandfather, why are you screaming into my ears?". ${ }^{18}$

After the two human beings have been created, the debata advises them to remain on this earth that he has made and to make it beautiful. He teaches them how to cook and eat food, to prepare fields and to plant crops. The two humans then ask to be instructed in all things that must be done by living beings, so that they will know what to do. The answer is as follows (Van der Tuuk 1860-62, Bataksch Leesboek III: 20):

"It's allright, grandchildren", the debata said. Then he made a sun and a moon, and then he made night and day. And he planted all the various [plants] that are here below the sky. When the debata had finished making all that grows, he

17 Asa mongkam mo debata idi: "Ue ale kak. Tuhu ngo katamu idi, asa mersiperidahen kita tuhu". Bagi mo nina. Asa menter isebut mo kunuken siualuh desa, asa menter mo tuhu terang kerina idah ladang.

18 Kenca bagidi kunuken, asa igana debata idi mo tanoh idi. Dua ibahan niperjelma, sada ibakin cumanen daholi, sada ibakin cumanen daberu. Kenca sun igana si dua idi, asa icinar mo i ari, asa kerah. Kenca kerah kunuken lebèken, kenca empihir tanoh si niganana idi, asa itabasi mo kunuken. Kenca itabasi, asa iubung mo. Kenca iubung kunuken pitu kali, asa menter mo merkesah. Kenca merkesah, asa itabasken nola mo tabas penungkuni. Kenca itabasken, asa iperkataken debata idi mo kunuken. Menter mo mengaloi: "Kade bangku ale empung, asa iselkingi kono penggelku idi?" Bagi mo kata si niganana idi. 
told the names of all he had made. After that he instructed which [plants] of all he had planted can be eaten, and which are not to be eaten. And he instructed that the day is for working and travelling, the night is for sleeping. And he also taught [them] to wear clothes. When he had taught [them] all that, the debata went up again. ${ }^{19}$

\section{A TOBA STORY OF ORIGIN}

The Dairi creation-story is not unique in Van der Tuuk's collection, there are several Toba stories about the beginning of the earth (mula ni tano), either transcribed from texts on tree-bark or bamboo, or originally written on paper. A Toba creation-story in MS Or. 3400: 258-277 that was written on paper with a Batak pen (tarugi) tells how the first settlement on earth came into being, but unlike the Dairi creation story it has not been included in the Batak reader. ${ }^{20}$ This Toba story must have been written before 5 May 1852, when Van der Tuuk sent a somewhat shortened Dutch translation of it in a letter to the Dutch Bible Society (Groeneboer 2002: 138-142). While the words "mula ni tano" have been written in the margin of the first page of the story, probably by Van der Tuuk, his Dutch translation of it is entitled "De eerste vesting" ('The first fortress'). As no earth is mentioned in this story, no sun or moon or human beings are being created either, the title of the translation in fact accurately reflects the contents.

The Toba creation-story in MS Or. 3400 tells how first a mandi-swallow, then the bird Patia Raja and later a bumblebee, are sent down by Ompu Tuan Batara Guru doli, who is a male "debata di atas", a god [dwelling] high in the sky. When a strong wind makes it impossible for the birds to return to their heavenly dwelling-place, the daughter of the ruler (boru ni raja) Si Tapi Sindar di Mata ni Ari helps them to create the first settlement beneath the sky near the rock Tanjuk Tolu.

All the ingredients for this first settlement on earth are let down from the sky by Tapi Sindar di Mata ni Ari. When she hears the bird Patia Raja's weeping she goes to the gate of the sky taking a magic ring and seven chicken's eggs, and tells him to stop weeping. As he cannot return, she lowers the magic ring and the eggs, telling him to take these to the rock Tanjuk Tolu. There the magic eggs are opened and various plants and trees pour out, the magic ring gives domestic and other animals, houses and whatever they want. Then the three animals make a feast where the bird Patia Raja becomes the ruler, the swallow the viceroy and the bumblebee the general. They ask Batara Guru

19 "Ue ale kempu", dok debata idi. Asa ibahan debata idi mo kunuken sada mata ni ari, ibahan mo sada bulan. Kenca bagidi kunuken, asa ibahan debata idi mo berngin deket mahar. Asa isuan mo nasa si masa nasa si lotna i teruh ni langgam ena. Kenca kerina kuh ibakin debata idi nasa gumana si tubuh, asa ibagah-bagahken mo kerina gerar nasa si nibahanna idi. Kenca bagidi, asa itenahi debata idi mo kunuken nasa si terpangan nasa sinuanna idi, itenahi deket so mada jadi panganen. Asa itenahi mo mahar ni ari pencametenken deket perdalanenken, berngin pedemenken. Asa iajari mo deket merabit. Kenca kerina iajarken, asa molih mo kunuken debata idi mi datas.

20 In his Codices Batacici, Voorhoeve remarks that two other stories written in a similar manner in the same manuscript mention the name of Guru Saniang Naga as Van der Tuuk's teacher - and possibly the author of these stories (Voorhoeve 1977: 107-108). 
Doli for offspring to populate their settlement. As in the Dairi creation story, this is done by introducing another character, Batara Guru's sister, who is let down in a basket together with the pregnant bird Imbulu Man.

In contrast with the Dairi story about the origin of the earth, the Toba Mula ni Tano story opens with a prayer addressing Ompung (grandfather, honorific) Debata (god, or gods), the god(s), above:

Asa manomba ahu di da ompung debata tian toding debata di atas, ahu na mangido sangap doahu, na mangido badia, na mangido tua doahu. Asa pitu hali manomba doahu, ale ompung, asa hutaringoti ma ho, ale ompung na mian di toding debata diatas (MS Or. 3400: 258, see Illustration 4).
Well I worship you Ompung Debata, gods dwelling above, I humbly ask you in my prayer for bliss, I ask you for glory [and] well-being in my prayer. Seven times I worship you in my prayer, oh Ompung, let me speak about you, who is [are] dwelling in the place of the gods above. ${ }^{21}$

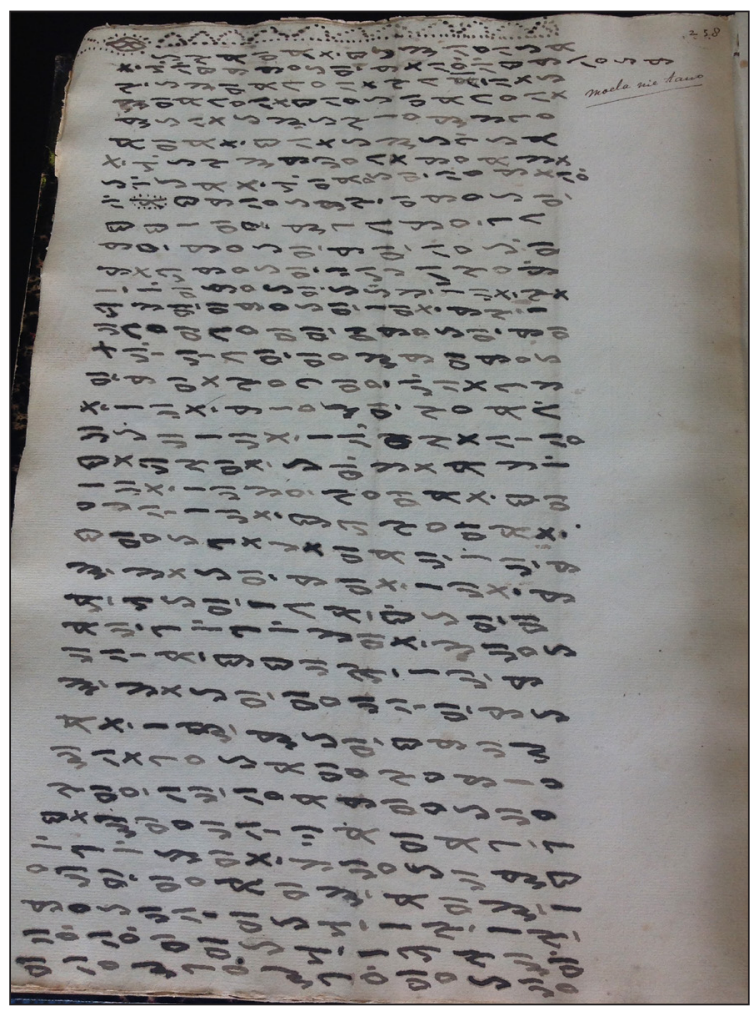

Illustration 4. MS Or. 3400: 258, Mula ni tano.

21 Van der Tuuk's Dutch translation reads: 'Met eerbied vouw ik mij de handen boven het hoofd voor $\mathrm{u}$, Goden daar boven! Met ootmoed smeek ik $\mathrm{u}$ om heil, heerlijkheid en geluk! Zevenmaal vergiffenis, Heere! voor het vermelden van uwen naam, Batara Goeroe Dooli, die onder de boven-goden heerscht!' (Groeneboer 2002: 138). 
A striking difference between the Dairi and Toba creation-stories is the role played by the god who dwells in the sky: while in the Dairi story the debata descends several times to personally create the earth as well as its inhabitants, in the Toba story Batara Guru remains in the sky, he does not go down to create the first settlement on earth. In fact, in the Toba story this creation is brought about by animals with the help of Batara Guru's daughter Si Tapi Sindar di Mata ni Ari - who does not come down either.

This Toba creation-story, which must have been written not long after Van der Tuuk's arrival in Barus, opens with an invocation to the gods, as is usual for a story told during a ritual. The Dairi creation-story, without such an opening prayer, was almost certainly written at a later date, when Van der Tuuk could supply a proper pen and ample paper enabling Guru Tinuturen to write his relatively long story in narrative style. As his knowledge of the language and culture improved over the years, Van der Tuuk's influence on the stories that were written for him must have grown stronger than in the period just after his arrival.

\section{VAN DER TUUK'S INFLUENCE ON STORIES IN THE BATAK READER}

Van der Tuuk must have influenced the stories that were written for him, as he writes in his letter to the Dutch Bible Society that he has to sit with the person who puts the story into writing and correct as much as possible his "unclear manner of expression" (Groeneboer 2002: 151). Although it is difficult to prove this influence, it is posssible to find traces of changes in the text by comparing the stories that were written in the manuscripts with the same stories as published by Van der Tuuk in the Batak Reader. If the same story has been kept in more than one manuscript, the written texts can be compared with each other and with the story published in the Batak Reader.

As discussed above, the introduction of the Dairi creation story "Permungkahen pertengahen ena" in manuscript MS Or. 3421 has been omitted from MS Or. 3420 and the Batak Reader. Yet, the closing passage of MS Or. 3421 has been included in MS Or. 3420 as well as in the Batak Reader. The brief summary of the story in the last passage of MS Or. 3421 has even been extended and moreover two four-line verses have been added as a formal closure - verses which are also used to end other stories in Van der Tuuk's collection. ${ }^{22}$ In other respects, the two handwritten texts of the Dairi creationstory do not essentially differ from each other or from the printed text, as in the three following examples, showing minor differences such as changes in word-order, specifying the person addressed, and omitting a suffix:

22 The final verse, quoted in Tindi Radja Manik's Dairi-Pakpak - Indonesian dictionary (2002), is also used to end the story of Kerbo Si Ranggir (Brakel-Papenhuyzen 2014: 328). 
1. Changed word-order:

MS Or. 3421: 28 - Bagi mo kunuken kata debata idi.

These were, they say, the words of the god.

MS Or. 3420: 392 and Van der Tuuk 1860-62, Bataksch Leesboek III: 2 - Bagi mo kata debata idi kunuken.

These were the words of the god, they say.

2. Specifying the person addressed:

MS Or. 3421: 29 - Asa mongkam mo debata idi bai Si Aji Guru: "Endengken kene mo ale merburu idi".

So the god spoke to Si Aji Guru: "Well, you must continue to hunt". MS Or. 3420: 392 and Van der Tuuk 1860-62, Bataksch Leesboek III: 3 - Asa mongkam mo debata idi bai Si Aji Guru: "Endengken kene mo ale Aji Guru merburu idi".

So the god spoke to Si Aji Guru: "Well Aji Guru, you must continue to hunt".

3. Omitting a suffix:

MS Or. 3421: 27 - Ia karnana asa susur ia kunuken mi teruh ena.

Now the reason why he descended, they say, down (here).

MS Or. 3420: 392 - Ia karna asa susur ia kunuken mi teruh ena.

Now the reason that he descended, they say, down (here)

Van der Tuuk 1860-62, Bataksch Leesboek III: 1 - Ia karnana asa susur ia kunuken mi teruh ena

\section{THE STORY OF KERBO SI RANGGIR}

The third Dairi story in the Batak Reader, about a female water-buffalo named Kerbo Si Ranggir, is also kept in two manuscripts of the Leiden collection: MS Or. 3403: 155-188 and MS Or. 3420: 333-360. In the fourth volume of the Batak Reader, Van der Tuuk makes the following remark on its content: "This is one of the many stories in which the Batak make a human being descend from an animal, indicating that they believe in reincarnation of the soul. This buffalo Ranggir has seven daughters, whom she has hidden in the jungle. Later, when she has become a human being herself, she brings them to the family of her husband". (Van der Tuuk 1860-62, Bataksch Leesboek IV: 78). ${ }^{23}$

The text of Kerbo Si Ranggir in manuscript MS Or. 3420: 333-360, written in a small, regular handwriting, is similar to the text in the Batak Reader and may have been written by Van der Tuuk himself, while the text in MS Or. 3403: 155-188, which has many corrections and deviations from the story in the Batak Reader, must be an earlier version. From the very beginning, the texts

23 The remark reads in Dutch: "Dit is een der talrijke verhalen, waarin de Batak menschen van dieren doet afstammen, en toont niet vrij te zijn van 't geloof aan de zielsverhuizing. De buffel Ranggir heeft hier zeven dochters, die zij in ' $t$ bosch heeft verborgen, en daarna, nadat zij zelve een mensch was geworden, bij de familie van haren man brengt". (Van der Tuuk 1860-62, Bataksch Leesboek IV: 78). 
in MS Or. 3403 and MS Or. 3420 differ: in MS Or. 3403 there is just one simple introductory phrase: "Now there is, they say, the story of a young woman [lit.: wearing a blouse], for the friends [who are] young girls" (Asa lot mo kunuken sukut-sukuten daberu si merbaju bai kaltuna daberu anak-anak).

This brief introduction has been extended in MS Or. 3420 and in the Batak Reader, adding that the purpose of the text is: "to be told to girls in the future, so that people will know the story and then likewise [will] tell it [to others]", and, addressing Van der Tuuk, says: "and it is told next to you, who is interested in written stories" (Asa lot mo kunuken sukut-sukuten daberu sada bage arnia kunuken kenca nola bagenda en, asa nisukutken nola mo lako bamu ale merkesekelken surat sukuten) (Van der Tuuk 1860-62, Bataksch Leesboek III: 76).

Besides minor changes, the texts in MS Or. 3403 and MS Or. 3420 frequently differ more extensively, when not only phrases but entire passages have been inserted into the text of MS Or. 3403. Below are three examples of small differences, such as changed word-order, specifying the person addressed, or changing an affix, followed by a longer fragment with additional passages inserted into the text in MS Or. 3403:

1. Changes in word-order:

MS Or. 3403: 155 - Kenca sun kunuken ibahan bagas Anak ni Aji perkerbo idi.

When Anak ni Aji's buffalo-shaped house was finished, they say.

MS Or. 3420: 333 - Kenca sun kunuken ibahan Anak ni Aji idi bagasna idi

When Anak ni Aji had finished, they say, making his house.

Van der Tuuk 1860-62, Bataksch Leesboek III: 76 - Kenca sun kunuken ibahan Anak ni Aji idi bagas idi.

When Anak ni Aji had finished, they say, making the house.

2. Specifying the person addressed:

MS Or. 3403: 155 - Asa mongkam mo anakna idi: "Idi sada kerbonta Si Ranggir". And his son spoke: "We have one water-buffalo Si Ranggir [lit.: here is our one water buffalo].

MS Or. 3420: 333 and Van der Tuuk 1860-62, Bataksch Leesboek III: 76 - Asa mongkam mo anakna idi: "Idi ale pa, kerbonta Si Ranggir i jalangen".

And his son spoke: "Father, here is our water-buffalo Si Ranggir in the meadow".

3. Omitting an affix

MS Or. 3403: 155 - asa mersisungkunen mo Anak ni Aji deket anakna Si Aji Tonggel.

And Anak ni Aji deliberated with his son Aji Tonggel.

MS Or. 3420: 333 and Van der Tuuk 1860-62, Bataksch Leesboek III: 76- asa mersungkunen mo Anak ni Aji deket anakna Si Aji Tonggel.

And Anak ni Aji consulted his son Aji Tonggel. 
4. MS Or. 3403: 161-162, Kerbo Si Ranggir predicts her own death

Bagi mo kata kerbo Si Ranggir mendokken beruna si pitu idi. Asa menter mo samah tangis kerina beruna si pitu idi, tangis deket kerbo Si Ranggir. Mersisahutsahuten mo ia. --- [crossed out] Kenca mersisahut-sahuten ia, asa laus mo kerbo Siranggir.

Soh kenca ia i kesean. Asa idokken mo: "Muda cakcik idah kene pelian, golok ni deba mo meneat inangmu aku, deket kujur memantem inangmu aku. Muda rendes ngo udan roh mi saponta ena, daroh inangmu aku mo kepeken, mersara-sara ibakin Anak ni Aji. Muda merkata ngo renggur, makini mi koden mo kalak sukasuka inangmu aku. Idi mo mahan alaten endene, ale inang, asa ibetoh kene mate inangendene aku". Bagi mo dok kerbo Si Ranggir mendokken bai beruna si pitu idi.
These were the words kerbo Si Ranggir spoke to her seven daughters. Then they all wept, all the seven daughters weeping together with kerbo Si Ranggir. They took leave from each other - and after that, kerbo Si Ranggir went away.

When she arrived in the village square, she said: "When you see the lightning flash, the people's sword is slaughtering me, your mother, and the javelin hits your mother. When the rain pours down on our house, [it's] just the blood of me, your mother, made to spout around by Anak ni Aji. When the thunder roars, people bring the flesh of your mother's body to the kitchen. This is an explanation for you, oh daughters, so that you'll know [when] I, your mother, [will have] died". That is what kerbo Si Ranggir said to her seven daughters.

\section{MS Or. 3420: 338-339, Van der Tuuk 1860-62, Bataksch Leesboek III: 83-84}

Bagi mo kata kerbo Si Ranggir mendokken beruna si pitu kalak idi. Kenca bagidi kata inangna idi kunuken bai beruna si pitu kalak idi, kenca bagidi kata kerbo Si Ranggir asa menter mo kunuken samah tangis kerina kunuken beru kerbo Si Ranggir idi, tangis mo deket kerbo Si Ranggir. Menter mo kunuken mersisahutsahuten ia. Kenca mersisahut-sahuten ia, asa laus mo kunuken kerbo Si Ranggir.

Kenca soh ia mi kesean sapo beruna idi, asa itenggoken kerbo Si Ranggir mo kunuken katana bai beruna si pitu (339) kalak idi: "O inang, kene berungku si pitu kalak idi. Dengkoh kene tenahku ena.
These were the words kerbo Si Ranggir spoke to the group of her seven daughters. After the mother had spoken these words, they say, to the group of her seven daughters, when kerbo Si Ranggir had said this, then, they say, they all wept together, they say, these seven daughters of kerbo Si Ranggir, [and] kerbo Si Ranggir wept with them. Then, they say, they took leave from each other. After they had taken leave from each other, kerbo Si Ranggir left, they say.

When she had arrived in the yard [in front] of her daughter's house, kerbo Si Ranggir called, they say, speaking to the group of her seven daughters: "Oh inang, you who are my seven daughters, listen to my instruction. 
Muda cakcik ngo idah kene pelian, ale inang, golok ni deba mo meneat inangmu aku, deket kujur ni deba mo meman-(84) tem inangmu aku. Muda rendes ngo idah kene, ale inang, udan roh mi sapoendene, ale inang, daroh inang endene aku mo kepeken, ale inang, mersara-sara ibakin Anak ni Aji. Muda merkata ngo idengkoh kene, ale inang, i babo saponta ena renggur, makini mi koden mo kalak mertasakken suka-suka inangmu aku. Bagimo katangku baindene inang, asa ibetoh kene mahan alatenkendene, ale inang, asa kutenahi kene, ale inang bagidi, asa ibetoh kene mo ale inang, inangendene aku mate ibakin deba." Bagidi mo idokken kerbo Si Ranggir mendokken bai beruna si pitu kalak idi.
When you see the lightning flash, oh inang, the people's sword is slaughtering me, your mother, and the people's javelin hits your mother. When you, oh inang, see the rain pouring down on your house, inang, [it's] just the blood of me, your mother, inang, made to spout around by Anak ni Aji. When you hear, inang, the thunder roaring above our house, people bring the flesh of your mother's body to the kitchen to cook it. I say this to you inang, so that you [will] know [to interpret] the signs, inang, and I instruct you, inang, so that you'll know, inang, that I, your mother, has been killed by people". That is what kerbo Si Ranggir said to the group of her seven daughters.

In the above example the text of Kerbo Si Ranggir in MSOr. 3403 clearly serves as the basis for the text in MS Or. 3420 and in the Batak Reader. In my view, the extra specifications of the speaker(s) and the person(s) addressed, before as well as after every expression in direct speech, and other additions to the text of Kerbo Si Ranggir in MS Or. 3420 and the Batak Reader are superfluous and make for tedious reading rather than improving the text. As similar additions occur in other stories that were written for Van der Tuuk (Brakel-Papenhuyzen 2014: 83-84), these are probably the result of Van der Tuuk's interference.

Besides influencing the style, Van der Tuuk must also have influenced the content and the topics of the stories that were written for him. Understandably, many stories in the Batak Reader have an educational value, and erotics are absent - though there are some stories in Van der Tuuk's collection that have an erotic theme. His interest in religion and social organisation even led to the creation of the novel genre of prose texts with information on legal matters (hukum), local customs (adat) and explanations of ritual and religious concepts, which also proved very useful to scholars, missionaries and administrators. Yet, such prose texts were not included in the Batak Reader.

\section{AIM OF THE BATAK READER}

As there is no statement about the aim of the Batak Reader (Bataksch Leesboek) in a Preface or Introduction, it is left to the reader's imagination to determine this. In a letter to the Dutch Bible Society dated 5 May 1852, Van der Tuuk argues that a complete collection of Batak stories forms the best source for getting to know Batak concepts about the gods, because questions about this 
are not answered, and most of the Batak gods only occur in stories. ${ }^{24}$ While it is doubtful that his employers had any interest in Batak stories and their divinities, Van der Tuuk himself apparently regarded the stories that were written for him as an important source of information, and so did other scholars and missionaries. ${ }^{25}$

In his foreword to the English edition of Van der Tuuk's Toba Batak Grammar, Teeuw writes that: "his grammar is certainly not a description of spoken Batak. It is based on the written language", and adds that Van der Tuuk collected so many written (story-)texts because "his principle was that the description of a language should be based on texts as recorded by the speakers of the language" (Van der Tuuk 1971: XXI).

On the other hand, Van der Tuuk's interest in written versions of stories may also be connected with his task - which he considered very difficult - to produce a translation of "the Bible" in Batak languages (Van der Tuuk 1971: XVVI). His first attempt, a Toba version of the creation-story in the book Genesis based on a biblical reader by Zahn (1842), entitled: De scheppingsgeschiedenis, volgens Genesis I, overgebragt in de taal de Bataks was published by the Dutch Bible Society in 1853. In the beginning of 1854 Van der Tuuk reported that this booklet did not interest the "heathen" Batak who worked for him, only those who had converted to Islam found its contents of interest (Groeneboer 2002: 165-166).

\section{CONCLUDING REMARKS}

In the Preface to Part Two of his Toba Batak Grammar (1971: XLIV), Van der Tuuk remarks that: "A language has to be studied for its own sake; it should not be made subservient to an end of which the pursuit acts to the detriment of its study". Possibly he foresaw that the stories and information on religion and adat he collected in North Sumatra could also contribute to the decline of religious practices and local customs such as storytelling.

Unlike the writers of his stories, Van der Tuuk did not specify in an introduction which type of reader he had in mind or why these stories had been selected for publication in his Bataksch Leesboek. In some letters to the Dutch Bible Society Van der Tuuk points out that Batak stories must be published in order to create an interest among the Batak population in reading printed books - and ultimately in reading the Bible. ${ }^{26}$ Therefore it is possible that Van

24 “Een volledige verzameling dezer verhalen is de bron waaruit men de godenleer zou kunnen te weten krijgen, want met vragen daaromtrent vordert men niet magtig, daar een groot gedeelte der Battaksche goden slechts in de verhalen figureren, en men dus weinig van hen zal vernemen zoo men zich niet de moeite getroosten wil die verhalen te bestuderen" (Van der Tuuk 1852 quoted in Groeneboer 2002: 136).

25 In an article on the "Religion of the Batak people" Niemann wrote that the story of Kerbo Si Ranggir is important because it describes the ritual for the inauguration of a new house (Niemann 1870: 305).

${ }_{26}$ "Misschien zal hij [de Batak] meerdere leeslust krijgen zoo hem op eene goedkoope wijze zijne eigene verhalen in de hand gewerkt worden. Eens eenige leeslust bezittende zal hij er misschien toe overgaan eene vertaling als die van Zahn's bijbelsche verhalen te doorleezen 
der Tuuk originally composed his Batak Reader for a local public, just like his Malay Reader (published in 1868), was intended for the "indigenous people" (als Leesboek voor den Inlander bestemd). In some of his later letters he points out that the stories need to be published to help preserve the Batak language and identity (Groeneboer 2002: 292-293).

However, the Dutch Bible Society decided not to cooperate in publishing the Batak stories he had collected (Groeneboer 2002: 354, note 4), and the Toba Batak Reader that Van der Tuuk had wished to distribute in North Sumatra (Brakel-Papenhuyzen 2014: 57, note 10) never appeared. It is possible that Van der Tuuk prepared the Batak Reader not only for the use of Dutch students who wished to learn Batak languages - he may also have been intended it as a means to help preserve the language and culture of the Batak peoples in North Sumatra. As western influence on the way of life of people in North Sumatra increased in the course of the twentieth century, the writing of stories developed from a mere summary - which served as an aide-memoire - into an independent literary genre. Whether or not such published versions of stories have become more important than storytelling, the Dairi stories in the Batak Reader remain interesting to this day, if only because they provide a unique insight into the way of life and thinking of the people who were living in Dairi during the mid-nineteenth century.

en daardoor eenigszins tot eene eigentlijk gezegde bijbelvertaling voorbereid worden" (Van der Tuuk 1854 quoted in Groeneboer 2002: 198-199). 


\section{APPENDIX I}

Summary of the story "Permungkahen pertengahen ena"

The God who is high in the sky, Debata i datas langit, tells his hunter Aji Guru to get a pregnant male mousedeer because his wife who is pregnant wishes to eat it. Aji Guru goes hunting with his dogs but cannot find one. Then he sends a crow to go and find it. The crow flies down into a deep, dark abyss from where he cannot return. He takes a rest on a piece of bamboo that floats on the water.

Debata i datas langit goes down accompanied by his helpers in flyingjackets to find the crow. At his request the debata creates light, the earth and two trees, then returns. A mandi-swallow is sent to keep the crow company and act as a messenger. At the request of the birds, Debata i datas langit descends again. He sends the swallow to get earth from his wife and creates a man and a woman from this earth. Then he instructs them how to survive by planting crops.

The wife of Debata i datas langit predicts the mysterious arrival of a third human being on earth. Then a young man emerges from inside a piece of bamboo. Debata i datas langit who is asked to come down again advises the three people to live in harmony.

A quarrel ensues between the two men about the woman, who is married to the first man. The bamboo-born man changes himself into a fruit. When the woman, who is pregnant, has eaten it, she gives birth to two boys. Debata i datas langit comes down again, instructs the father to prepare a feast and gives the children a name. When another son is born, Debata i datas langit descends for the last time and gives him a name. After that a girl is born, Beru Alahen. When the parents die, the swallow is sent up to ask instructions from Debata $i$ datas langit and learns how to carry out the burial of the first human couple.

Nabi Setan, one of the three brothers, marries his sister Beru Alahen. She gives birth to two daughters, who are given as wives to the two other brothers. Their descendants populate the earth. (Van der Tuuk 1960-62, Bataksch Leesboek III: 1-43). 


\section{APPENDIX II}

\section{Summary of the story "Mula ni Tano"}

This story opens with a prayer to Ompung Debata tian toding debata di atas, the God(s) above, followed by a description of the heavenly abode of Batara Guru Doli, ruler (raja) of a settlement similar to a Toba village chief. The main actor in the story is Batara Guru's daughter (beru $n$ raja) Si Tapi Sindar Di Mata Ni Ari, who becomes sad when looking down from the gate of the sky she sees an empty plain. A mandi-swallow who is sent down to have a look cannot return and takes a rest on the rock Tanjuk Tolu. The heavenly bird Patia Raja is sent down to look for the swallow - he cannot return because the wind is too strong.

When the two birds do not return, a bumblebee is sent down by Si Tapi Sindar di Mata ni Ari. He finally finds the two birds sitting on the rock and asks: "Why don't you come back - the princess is worried". The three of them go to the rock Nanggar Jati. The bird Patia Raja climbs up and tries to grasp the roots of the Jambar Barus tree above him, but fails, and weeps.

When Si Tapi Sindar di Mata ni Ari hears him weeping she opens her gambir-box. She goes to the gate of the sky taking a magic ring and seven chicken's eggs, then tells him to stop weeping and come back, but he cannot. She lowers the magic ring and the seven eggs, telling him to go to the rock Tanjuk Tolu and open the eggs. Inside these are various plants and trees. The magic ring will give domestic and other animals, houses and what they want. The three of them do this and when they have all they want make a feast. Patia Raja becomes the ruler, the swallow viceroy and the bumblebee general. They ask Batara Guru Doli for offspring to populate their settlement.

Batara Guru hears the prayer and tells his sister Pandan Rumari to go down. "But brother how do I get there"? When princess Si Tapi Sindar di Mata ni Ari promises to make it easy she agrees, and is let down to the top of Batu Nanggar Jati in a basket made from the princess' hair, taking a magic ring with her. At the foot of the mountain she choses a place to live named Pulo Porlak Pagaran. At the time indicated by the princess she goes to the top and tries in vain to catch the roots of the Jambu Barus tree.

Si Tapi Sindar di Mata ni Ari hears the weeping of her aunt and goes to the gate of the sky. Remembering her promise she lets down a jacket, a jaw's harp, earrings, a mirror and seven kinds of citrus fruit. She tells her aunt to go down the mountain and take the bird Imbulu Man with her, who is pregnant with a human baby. The bird gets a sleeping-place with mats as curtains.

One day Pandan Rumari lights a fire, the three animals in Tanjuk Tolu see the smoke and the swallow is sent to see who is living there. Pandan Rumari tells him Batara Guru doli has sent her. The pregnant Imbulu Man follows the swallow to Tanjuk Tolu and tells Patia Raja that she has been sent by the princess to give them her offspring. Later, when the two birds marry Imbulu Man's daughters and the bumblebee sleeps with her, the settlement on earth becomes populated. 
REFERENCES

MANUSCRIPT SOURCES

(Leiden University Library)

MS Or. 3399: 120-171, Guru Tonggal Begu [Pemere Beru Si Pitu]

MS Or. 3400: 258-77, Mula ni Tano

MS Or. 3403: 155-188, Kerbo Si Ranggir

MS Or. 3406: 170/175 -173/178, Datu Tonggal ni Begu

MS Or. 3420: 392-412, Permungkahen pertengahen ena

MS Or. 3421: 27-54, Permungkahen pertengahen ena

\section{PUBLICATIONS}

Angerler, J. 2016. "Images of God in Toba Batak storytelling". [In this volume.] Brakel-Papenhuyzen, C. 2004. "The birth of Jaka Tarub, a hero from northern Java", in: Jan Jansen and Henk M. J. Maier (eds), Epic adventures, heroic narrative in the oral performance traditions of four continents, pp. 22-34. Münster: LIT Verlag.

Brakel-Papenhuyzen, C. 2014. Dairi stories and Pakpak storytelling; A storytelling tradition from the North Sumatran Rainforest. Leiden: Brill. [Verhandelingen van het Koninklijk Instituut voor Taal-, Land- en Volkenkunde vol. 279.]

Ginting, J.R. 1990. "Pa Surdam, ein Guru der Karo-Batak", in: Achim Sibeth (ed.), Mit den Ahnen leben; Batak Menschen in Indonesien, pp. 85-100, Stuttgart/London: Hansjorg Mayer.

Groeneboer, K. 2002. Een vorst onder de taalgeleerden; Herman Neubronner van der Tuuk, Taalafgevaardigde voor Indië van het Nederlandsch Bijbelgenootschap, 1847-1873. Leiden: KITLV Uitgeverij.

Kozok, U. 2000. "On writing the not-to-be-read; Literature and literacy in a precolonial 'tribal' society", Bijdragen tot de Taal-, Land-en Volkenkunde 156/1: 33-55.

Moore, Lynette M. 1985. Songs of the Pakpak of North Sumatra. Unpublished PhD Thesis, Monash University, Melbourne.

Niemann, G.K. 1870. "Bijdrage tot de kennis van den godsdienst der Bataks", Tijdschrift voor Nederlandsch-Indië 1870, I: 288-308.

Ras, J.J. 1968. Hikajat Bandjar; A study in Malay historiography. The Hague: Martinus Nijhoff.

Teeuw, A. 1971. "Foreword”, in: H.N. van der Tuuk, A grammar of Toba Batak. The Hague: Martinus Nijhoff.

Tindi Radja Manik. 2002. Kamus Pakpak-Indonesia. Medan: Penerbit Bina Media.

Tuuk, H. Neubronner van der. 1853. De scheppingsgeschiedenis, volgens Genesis I, overgebragt in de taal der Bataks. Gedrukt voor het Nederlandsch Bijbelgenootschap. Amsterdam: Nederlandsch Bijbelgenootschap.

Tuuk, H. Neubronner van der . 1856 "Over schrift en uitspraak der Tobasche taal, als eerste hoofdstuk eener Spraakkunst", Bijdragen tot de Taal-, Land-en Volkenkunde 4: 1-54. 
Tuuk, H. Neubronner van der. 1860-62. Bataksch Leesboek. Amsterdam: Frederik Muller. 4 vols.

Tuuk, H. Neubronner van der. 1861. Bataksch-Nederduitsch woordenboek. Amsterdam: F. Muller.

Tuuk, H. Neubronner van der. 1862. Taalkundige aantekeningen en bladwijzer vertaalde stukken en Inhoudsopgave tot de drie stukken van het Bataksche Leesboek. Amsterdam: Muller.

Tuuk, H. Neubronner van der. 1864-67. Tobasche spraakkunst. Amsterdam: Muller.

Tuuk, H. Neubronner van der. 1868. Maleisch leesboek voor eerstbeginnenden en meergevorderden; Zevende stukje: bevattende de vier Maleische vertellingen. Leiden: Brill.

Tuuk, H. Neubronner van der. 1971. A grammar of Toba Batak. The Hague: Martinus Nijhoff.

Voorhoeve, P. 1927. Overzicht van de volksverhalen der Bataks. Vlissingen: Van de Velde.

Voorhoeve, P. 1977. Codices Batacici. Leiden: Universitaire Pers. [Codices Manuscripti 19.]

Zahn, F.L. 1842. Bijbelsche geschiedenissen (naar het Hoogduitsch van Zahn). 's-Gravenhage: Roering. [Translation of: Biblische Historien, 1832.] 